$$
\text { Donka Attila - Gyuricza László }
$$

\title{
Az állam szerepe az aktív turizmus fejlesztésében
}

\section{The Role of the State in the Development of Active Tourism}

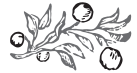

\section{Összefoglalás}

Az elmúlt bó egy évtizedben a hazai turizmus forgalmának dinamikus emelkedésével, illetve az európai uniós csatlakozással számos ágazati stratégia készült az egyes aktív turisztikai termékekre vonatkozóan is, elsôsorban az uniós tervezési idôszakokhoz igazodva. Mivel jelenleg az aktív turisztikai tevékenységek, illetve termékek nagyobb részének alacsony a jövedelemtermelô képessége, azok lassan indulnak el növekedési pályán. A forgalom lassú felíveléséhez az erôsen hiányos infrastruktúra is hozzájárul. Ezért különösen fontos, hogy az utóbbiak fejlesztéséhez központi források is kapcsolódjanak, akár a turistaházak, a kerékpárutak és más kerékpáros létesítmények, az ökoturizmus vagy a vízitúra-megállóhelyek terén. A kormányzati koncepcióban 2010-ben bekövetkezett változások is az ágazati és termékstratégiák újragondolását tették szükségessé. A tanulmány az egyes hazai, központi forrásból megvalósuló aktív turisztikai fejlesztések tartalmát és azok várható hatásait vizsgálja.

Journal of Economic Literature (JEL) kódok: L83, O18

Kulcsszavak: aktív turizmus, turizmusfejlesztés, pályázatok, kerékpáros turizmus, víziturizmus

\section{Summary}

In the past approximately fifteen years, with the rapid rise in domestic tourism turnover and Hungary's accession to the European Union, numerous sector strate-

Donka AtTila fốiskolai tanársegéd, Kodolányi János Főiskola, doktorjelölt, Pécsi Tudományegyetem Földtudományi Doktori Iskola (donkesz@ gamma.ttk.pte.hu), Dr. Gyuricza LÁszló egyetemi docens, Pécsi Tudományegyetem Földrajzi Intézet (gyuricza@gamma.ttk.pte.hu). 
gies were made for every product in active tourism. Due to the current low profitability of active tourism and the infrastructure gaps, growth is sluggish. For this reason, it is particularly important to contribute central funds for infrastructure development, whether for tourist lodges, cycle tracks, other cycling facilities, ecotourism or riverside stops. The 2010 changes in the government's concept required the reconsideration of sectoral and product strategies. The paper examines the active tourism development projects implemented from public funds, and their expected effects.

Journal of Economic Literature (JEL) codes: L83, O18

Keywords: active tourism, tourism development, tenders, cycling tourism

\section{BEVEZETÉS}

Az aktív turizmushoz tartozó tevékenységek egyúttal szabadidős sporttevékenységek is lehetnek, attól függóen, hogy az abban aktívan részt vevôk ezt saját lakóhelyükön vagy lakóhelyüktôl távol teszik. Egyes országokban, ahol az adottságok rendelkezésre állnak, és már felismerték az aktív turizmusban rejlő gazdasági potenciált is, az elméleti megalapozó tanulmányok mellett hasonlóan jelentós szerepük van a gyakorlati megvalósítás irányába tett lépéseknek.

Az aktív turizmus eddig végrehajtott és tervezett fejlesztései különös megvilágításba helyezik ezt a turisztikai terméket (termékcsoportot). Tekintettel arra, hogy az egyes aktivitások, mint valós vagy reménybeli turisztikai termékek, többsége viszonylag alacsony jövedelemtermeló képességgel rendelkezik, ha önmagában az ezekhez kapcsolódó vendégforgalomból származó bevételeket vizsgáljuk, csakugyan kérdéses a fejlesztések megtérülése. Ha azonban komplexebb módon, a teljes társadalmi-gazdasági hatásokat vesszük szemügyre (így a helyi lakosság életminôségéhez közvetlenül és közvetetten történố hozzájárulást is), akkor - bár nehezebben számszerúsíthetố mértékben - bátrabban lehet a fejlesztések megtérülésére számítani.

Az átgondolt, tervezett, a gazdaság összefüggéseit figyelembe vevô beruházások fenntartható módon járulnak hozzá az egyes térségekben a bevételek és a munkahelyek növekedéséhez. A tervezés azonban - éppen a kölcsönös összefüggések komplexitása révén - nem egy-egy vállalkozás vagy projektgazda feladata, annál jóval szélesebb területre kell kiterjednie. A tervezés gazdája sem azonos egy vállalkozással, hanem az adott terület gazdasági-politikai döntéshozóinak a feladata, partnerként bevonva a társadalom és a gazdaság minél szélesebb rétegeit.

A kutatások alapját a stratégiák tartalmi vizsgálata és a megvalósulás értékelése képezte. Ennek keretében sor került az aktív turizmusban végbement vagy folyamatban lévô fejlesztések számbavételére, továbbá a turisztikai fejlesztések hatékonyságának mérésére irányuló kutatások tanulmányozására. 


\section{A FEJLESZTÉSEK HATÉKONYSÁGÁNAK VIZSGÁlata}

A vállalkozásokat, illetve más, a fejlesztésben részt vevô szervezeteket, például az önkormányzatokat vagy a nonprofit szervezeteket nemcsak a jogszabályi környezet, hanem az elfogadott fejlesztési dokumentumok is keretek közé szorítják, különösen azokban az esetekben, ha olyan elképzelést igyekeznek megvalósítani, amelyhez támogatást is igénybe vesznek.

A stratégiák kidolgozása egy korábbi idôszakra, többnyire a 2007 és 2013 közötti évekre vonatkozóan történt, így az abban foglaltak felülvizsgálata esedékes. Tekintettel azonban arra, hogy sok esetben merész fejlesztési, fejlődési ütemmel terveztek, a kitúzött célok többségének megvalósulása még várat magára, így az újabb idôszakokra vonatkozó elképzelésekben is meg kell jelenniük ugyanazon (újragondolt) céloknak.

Mivel jelenleg az aktív turisztikai tevékenységek, illetve termékek nagyobb részének alacsony a jövedelemtermelố képessége, azok lassan indulnak el a növekedési pályán. A forgalom lassú felíveléséhez az erôsen hiányos infrastruktúra is hozzájárul. Ezért különösen fontos, hogy az utóbbiak fejlesztéséhez központi források is kapcsolódjanak, akár a turistaházak, a kerékpárutak és más kerékpáros létesítmények, az ökoturizmus vagy a vízitúra-megállóhelyek terén. A lovasturizmus kissé eltér az említett termékektôl, mivel ott csak komoly nagyságrendú beruházással jelenhet meg egy szolgáltató, ugyanakkor ennek a terméknek a jövedelemtermelô képessége is magasabb.

A turizmus nemzetgazdasági jelentőségével számos tanulmány foglalkozott (Nemes, 2009; Kovács-Gerlach, 2007; GKI Gazdaságkutató Zrt., 2005; stb.). A tervezés eredményeként létrejövố fejlesztések hatásai széles terepet kínálnak a kutatóknak. Dávid (2007), valamint Raffay és szerzótársai (Raffay et al., 2007) monitoringtevékenységet megalapozó tanulmányai útmutatóul szolgálnak az értékelésekhez. Az Állami Számvevôszék jelentése alapján készült tanulmányok (Mundruczó et al., 2010a; 2010b) mellett többen is foglalkoztak a turizmus elért eredményeivel. Ligeti (2006) és Braunné (2011) a turisztikai beruházások értékelésével, Aubert (2006) a turisztikai nagyberuházások hatásával, Budai (2001) a Széchenyi Terv kezdeti szakaszának, a MundruczóSzennyessy szerzópáros (2005a; 2005b) pedig a további egészségturisztikai fejlesztések hatásaival foglalkozik. ${ }^{1}$ Trón (2008) tanulmánya az uniós támogatások hatásának vizsgálatára terjed ki. A turizmus jövôjének speciálisabb, de egyre aktuálisabb kérdéskörével, a fejlesztések és a fenntarthatóság összefüggéseivel foglalkozik Vargáné (2005), Bajmócy és szerzôtársai (2012) gyújteményes munkája, illetve Inskeep (2000).

\section{A TERMÉSZETJÁRÁS HELYZETÉRTÉKELÉSE}

A kormányzati koncepcióban 2010-ben bekövetkezett változások is az ágazati és termékstratégiák újragondolását tették szükségessé. Az aktív turizmushoz kapcsolódóan bekövetkeztek továbbá olyan változások, amelyek meghatározók lehetnek a következô években a turisztikai termékek forgalmának alakulásában. A tanulmány az egyes hazai, központi forrásból megvalósuló aktív turisztikai fejlesztések tartalmát és azok várható hatásait vizsgálja. A legjelentôsebb változások a következók. 
Az Új Széchenyi Terv meghirdetése: Az Új Széchenyi Terv leginkább kiemelt eleme az egészségturizmus fejlesztése, és ez alatt nemcsak annak klasszikus területeit kell érteni, hanem az egészség megőrzése érdekében a szabadidősport-tevékenységeket is, ideértve az aktív turizmus keretében végzett sportolást is, mint a megelőzés, az egészség megốrzésének leginkább hatékony módját. Különleges jelentôsége van annak, hogy az elsố pályázati kiírások egyike, a 2012-ben meghirdetett szálláshelyfejlesztési pályázatok során a feltételek között szerepelt, hogy minden támogatásban részesüló szálláshelynek valamilyen kerékpáros szolgáltatást is ki kell alakítania (kölcsönzés vagy szerviz). Ez nagymértékben hozzájárult a kerékpáros infrastruktúra fejlődéséhez.

Átalakult a Magyar Természetbarát Szövetség: A Magyar Természetbarát Szövetség 2012-tôl új néven (Magyar Természetjáró Szövetség) folytatta munkáját, mellyel egyidejúleg a feladatai is átalakultak. A sportmozgalmi jelleget meghagyták, más területek azonban más szervezetekhez kerültek. Sokat elárul a szervezet által képviselt értékekkel kapcsolatos kormányzati szándékokról, hogy a szervezet új vezetőjének a természetjáró és kerékpáros turizmus fejlesztéséért felelôs miniszterelnöki megbízottat választották.

A vízitúrázással kapcsolatos számos feladat átkerült a Magyar Kajak-Kenu Szövetséghez: A sport, ezen belül is a szabadidősport mint feladatkör a Magyar Természetjáró Szövetségtôl átkerült a Magyar Kajak-Kenu Szövetséghez, ideértve a turisztikai kapcsolódásokat is. Bár a szövetség elsôdleges tevékenységei továbbra is a versenysporthoz kapcsolódnak, az új kihívásoknak is igyekeznek megfelelni, de a két terület élesebb elhatárolása még csak ezt követôen történik meg. A szervezet igyekezett minden bevált, vízitúrázással kapcsolatos elemet átvenni a természetjáróktól, ezek közé tartozik a túrázással kapcsolatos arculat és a jelzésrendszer is, melyben a vízitúrázás komoly lemaradásban van, mind más természetjáró ágazathoz, mind pedig külföldi térségekhez képest.

A Nemzeti Turistaház-fejlesztési Program meghirdetése: A gyalogos természetjárás széles körben elterjedt aktív turisztikai forma, egyike a legnépszerúbb szabadidô-eltöltési lehetôségeknek, amelyet az ország szinte bármely területén lehet végezni (Sulyok-Magyar, 2014). Részben ennek a népszerúségnek köszönhetô, hogy az aktív turizmust érintô fejlesztések elsố szakaszában a fôleg a gyalogtúrázáshoz kapcsolódó infrastruktúra-fejlesztésre került sor. A program elsô szakaszában, elsôsorban a belföldi aktív turizmus fellendítése érdekében, az ország 220 turistaháza közül 30-nak a felújítását határozták el. ${ }^{2}$ Az elsố körben helyet kapó létesítmények kiválasztására nem a turisztikai, forgalmi helyzet alapján került sor, az elsôdleges szempont a rendezett (állami) tulajdonviszonyok megléte volt.

A rendelkezésre bocsátott kétmilliárd forint keretösszegból átlagosan hatvanmillió forint jut egy létesítmény modernizálására, bár egyes helyszíneken - a különleges adottságokból adódóan - ennek többszörösét fordították az építkezésekre. Az eddig elkészült felújítások költsége 25 és 90 millió forint között mozgott, illetve a galyatetôi turistacentrum esetén hetvenmillió forintos költséggel épülhet meg a kilátó, és további 460 millió forintból maga a turistaház. A kiválasztási szempontok következtében, az elsố szakaszban eddig felújított szálláshelyek területi megoszlása egyenlőtlen. Míg 
a Pilisben és a Visegrádi-hegységben 7, a Mátrában 5, addig a Bakonyban csak 2, a Börzsönyben, a Bükkben pedig csak egy-egy házat újítottak fel.

A természetjárás kiemelt szerepét jelzi, hogy még a program meghirdetése előtt miniszterelnöki megbízottat neveztek ki a terület koordinálására, továbbá magát a programot nemzetgazdasági szempontból kiemelt programmá minôsítették. Ennek részeként az érintett szálláshelyeket a Nemzeti Sportközpontok vagyonkezelésébe adták, a hasznosító pedig a Magyar Természetjáró Szövetség.

A természetjárás turisztikai termékként történô fejlesztésének a következô lépése az elmúlt években - a speciális szálláshelyek mint alapvetó infrastrukturális feltételek fejlesztését követôen - az útvonalak felújítása volt. Annak ellenére, hogy az országban (a Magyar Természetjáró Szövetség adatai szerint) hozzávetőlegesen 24 ezer km jelzett turistaút van, a legnagyobb figyelem általában az Országos Kéktúra útvonalára irányul. A központi forrásból megvalósult fejlesztés során, 2013 és 2015 között hárommilliárd forint költséggel újították fel a túra 1160 km-es útvonalát. ${ }^{3}$ Ez nem csupán az útvonal infrastruktúráját (jelzéseket, pihenôket) érintette, hanem kerékpárral is igénybe vehetô szakaszokat is kialakítottak, továbbá különböző kedvezmények igénybevételére is alkalmas természetjáró kártyarendszert dolgoztak ki, valamint mobiltelefonos applikációt, online erdei szálláskeresôt és a Természetjárók Térinformatikai Rendszerét (www. ttrmap.hu). Egyeloore ugyan utóbbiak kevés tartalommal múködnek, és a népszerúsítésük sem kezdődött meg, de a technikai feltételek már adottak ahhoz, hogy az aktív turizmus valódi kínálati elemeivé váljanak.

Bejárható Magyarország Program meghirdetése: Az ismertetett kezdeti fejlesztések szinte kizárólag a gyalogos természetjárásra terjedtek ki. A tervezett, illetve részben már megkezdett folyamatban azonban már más aktivitási formák fejlesztése is megkezdódött. A Bejárható Magyarország Keretprogram a Svájcban alkalmazott SwitzerlandMobility rendszer hazai adaptációján alapul. A hazai rendszer öt turisztikai közlekedési módot (ún. jármódot) fog össze: lovaglás, vízitúrázás, gyalogtúrázás, kerékpározás és vitorlázás. A program célja egyrészt a belföldi turizmus erôsítése, másrészt az egészség- és környezettudatos szemléletmód kialakítása. Ennek keretében - állami közremúködéssel - termékfejlesztési feladatokat vállal fel, továbbá alapfokú tananyagok összeállításával és az oktatók motiválásával már gyermekkorban igyekszik kialakítani ezt a szemléletmódot. ${ }^{4}$

A Bejárható Magyarország Keretprogram céljai között megjelent a fogadóterületek helyi közösségeinek fejlôdése is. A program fontos részét képezi a marketingtevékenység, melynek keretében felhívják a belföldi lakosság figyelmét a hazai természeti értékekre. Az eszközök közül kiemelkedik az infrastruktúra - különösen a jelzésrendszerek -, a szolgáltatások és az attrakciók fejlesztése (például turistaházak, kerékpárutak, vízitúra-megállóhelyek, adatbázisok és kedvezményrendszerek kialakítása stb.). ${ }^{5}$ A program keretében kidolgozott képzési anyagok azonban egyelôre jellemzóen leíró jellegúek, így kevésbé teszik lehetôvé a résztvevôk számára a folyamatok és a tudományos kapcsolódások (így a turizmus rendszerének) megértését. A program társadalmi céljainak megfelelően ismeretterjesztő jellegú, annak tartalmi elemeiben a mozgalmi jelleg dominál. 
A központi fejlesztések során, az abban részt vevô partnerek a Magyar Természetjáró Szövetség mellett a civil szervezetek, az érintett önkormányzatok, az erdészetek, továbbá az egyházak lehetnek. Figyelemre méltó, hogy a turisztikai szolgáltatókat nem jelölték meg a partnerek között, holott azoknál is rendelkezésre áll a megfelelő szaktudás, bizonyos mértékig tôke is, illetve a többi szereplőtôl eltérốen, elsôdlegesen közgazdasági szempontok vezérlik a döntéseiket és tevékenységüket, ami alapvető feltétele annak, hogy a fejlesztésre kerülő turisztikai termékek ne csak a lakossági alapellátás részei legyenek, hanem valóban (növekvô) jövedelemtermelő képességgel rendelkezô tevékenységgé váljanak. Egy túraútvonalakkal foglalkozó korábbi tanulmány (Magosfa Alapítvány, 2010) már részletesen megfogalmazta, a helyi szolgáltatási hálózat kialakítása során jelentôs szerepet kell kapniuk a helyi turisztikai vállalkozásoknak is.

A turisztikai fejlesztések hatásának vizsgálata igen összetett kérdés. A fejlesztések folyamatossága megköveteli mind a legújabb fejlesztési elképzelések megalapozottságának, illetve azok megvalósítható stratégiai dokumentummá alakulásának (Aubert et al., 2007), mind pedig a várható, illetve a bekövetkezó hatásoknak a tudományos értékelését.

\section{MINôsítéSI RENDSZER A VÍZITÚRÁZÁSBAN}

A feladatok megosztását követően a Magyar Kajak-Kenu Szövetség más hangsúlyokkal kezdett el foglalkozni az evezés és a vízitúrázás kérdésével. Ennek keretében a mozgalmi jellegról áthelyezôdött a hangsúly a sportra. A szervezet tevékenységei az alábbiak szerint csoportosulnak: gyorsasági evezés (a klasszikus kajak-kenu versenyszámok), maratoni evezés (hosszú távú versenyzés), parakenu (fogyatékossággal élók sportja), sárkányhajózás (szintén versenyzés) és túrázás (összevonva a szelídvízi túrázást az idehaza alig elérhetô, tehát a belföldi turizmust nem szolgáló vadvízi evezéssel, továbbá a szúk réteget érintô kajakpólóval). Jól látható, hogy egyelőre igen kis szerep jut a szabadidôsportnak, illetve a túrázásnak, vélhetôen a szervezet több évtizedes hagyományaiból fakadóan. ${ }^{6}$ A turisztikai szakmai szempontok sporttal szemben történố háttérbe szorulásának jele az is, hogy a kialakításra kerüló, színvonalas szolgáltatásokat kínáló vízitúra-megállóhelyeket az elôzetes bejelentések szerint kajak-kenu pontoknak fogják hívni.

Az elmúlt évben nagyszabású kampányt indított a szervezet a vízitúrázás (és a Bejárható Magyarország Program) népszerúsítése érdekében, azonban ennek is a sporttevékenység állt a fókuszában, jóval kevésbé a turizmus. A kampányelemek között jól megválasztott szlogenekkel sikeresen szólították meg a fiatalokat („Azért a víz az út”, „Evezni mentem”).

A szervezet lehetôséget kapott arra is, hogy a vízitúrázáshoz kapcsolódó, országos vagy regionális hatású fejlesztések gazdája legyen. Továbbá központi szerepet kaptak a vízitúrázáshoz kapcsolódó minôsítési rendszer kidolgozásában is. Ezzel kapcsolatban meg kell jegyezni, hogy a természetjárással és vízitúrázással kapcsolatos feladatok fenti módon történt újraszervezésében továbbra is kevés szerepet kaptak a turisztikai szervezetek. Ez azonban azért következett be, mert az aktív turizmus nem jelenik 
meg markánsan a turizmus rendszerében, mint például a szolgáltatók (szálláshelyek, utazásszervezôk) vagy más termékek (egészségturizmus) képviselői. Így döntéshozói részrôl igyekeztek összekapcsolni a termék hátterét alkotó sporttevékenység szakmai szervezetét, illetve a hazai turizmusirányítás legmagasabb szintjét, és ezek szoros együttmúködésével folytatódott a munka, garantálva a turizmus szakszerú képviseletét a tervezés és fejlesztések során.

A Nemzetgazdasági Minisztériummal történô együttmúködés eredményeként sikeresen kidolgozták a vízitúra-megállóhelyek minôsítési rendszerét, így azok is bekerültek a turisztikai nemzeti tanúsító védjegyek közé (a falusi szálláshelyek, a vendégházak, a kempingek és üdülóházak, a szállodák, az ifjúsági szállások és a fürdôk mellett), emelve ezzel a vízitúrázás mint fejlesztendô turisztikai termék szerepét. ${ }^{7}$ A minôsítéseket 2015 júniusa óta adják ki a vízparti szolgáltatóknak. Egy évvel késóbb 50 szolgáltató rendelkezett minősítéssel, és további 28 szolgáltató adott be kérelmet. A minősítési rendszer igen komplex módon vizsgálja a megállóhelyen elérhető, a vízitúrázók számára nyújtott szolgáltatásokat. Ezek között szerepel a szállás- és étkezési lehetôség, a megközelíthetôség a szárazföld felől, a sportolási lehetőségek (köztük a leglényegesebb, a kikötési lehetôség minôsége) és az egyéb szolgáltatások (például evezésoktatás, sportszerjavítás, programlehetôségek stb.).

Az igen alapos minôsítési feltételek között kisebb ellentmondások fellelhetôk. Megállapíthatjuk, hogy a legalacsonyabb, egylapátos minôsítésnek igen könnyú megfelelni, ehhez tulajdonképpen nem kell semmiféle szolgáltatás. A vízvételi lehetôség, vécé, sátorozási lehetôség és tûzrakó hely gyakorlatilag számtalan táborozóhelyen megtalálható, ezek a legalapvetőbb feltételek, ezért elsôre feleslegesnek túnik a minôsítési rendszerbe beemelni ezt a kategóriát. Különösen nehezen érthetô, hogy a feltételek között helyet kapott az is, hogy van-e túraútvonal vagy kerékpárút a helyszínen. Ez azonban teljes mértékben irreleváns egy vízitúra-megállóhely esetén. Hiányzik azonban olyan alapvetô feltétel, mint a kikötési lehetôség.

Bár az eddigi minôsítések, illetve minôsítési szándékok még csak a kezdeti érdeklôdésnek tekinthetôk, több jellemzố már most megfigyelhetô. A szolgáltatók területi elhelyezkedése alapján látható, hogy azok száma, illetve súrúsége nem esik egybe a víziturizmus forgalmával, bár bizonyos párhuzamok tapasztalhatók. A szolgáltatók részérôl a legnagyobb az érdeklôdés a Felsô-Tisza-vidéken, illetve a Közép-Tisza-vidék felsố szakaszán, a Körösök mentén és a Ráckevei-Duna-ágban, miközben több jelentôs vízitúrázó célterületen (a Rába, az Alsó-Duna, a Bodrog, a Hernád és a Sajó mentén) egyelốre egyáltalán nincs minôsített túramegállóhely (1. ábra). Figyelemre méltó, hogy a folyó menti területekhez képest jobb infrastrukturális adottságokkal rendelkező Balaton-parton növekszik a bejelentkezett szolgáltatók száma, mivel ebben a térségben - a már eddig is kialakult szolgáltatási kínálat révén - szinte semmiféle fejlesztési igénnyel nem jár a minôsítés megszerzése. Ennek ellenére a vízitúrázás - a rendelkezésre álló, leginkább elterjedt és hozzáférhetô sporteszközök korlátai révén elsôsorban folyóvizeken lehetséges, így bizonytalanok lehetünk abban, vajon a kínálati oldalon elérhetô fejlett infrastruktúra képes lesz-e ellensúlyozni a vízitúrázás mindeddig alapvetônek tekintett vonzerőit és egyéb feltételeit. 


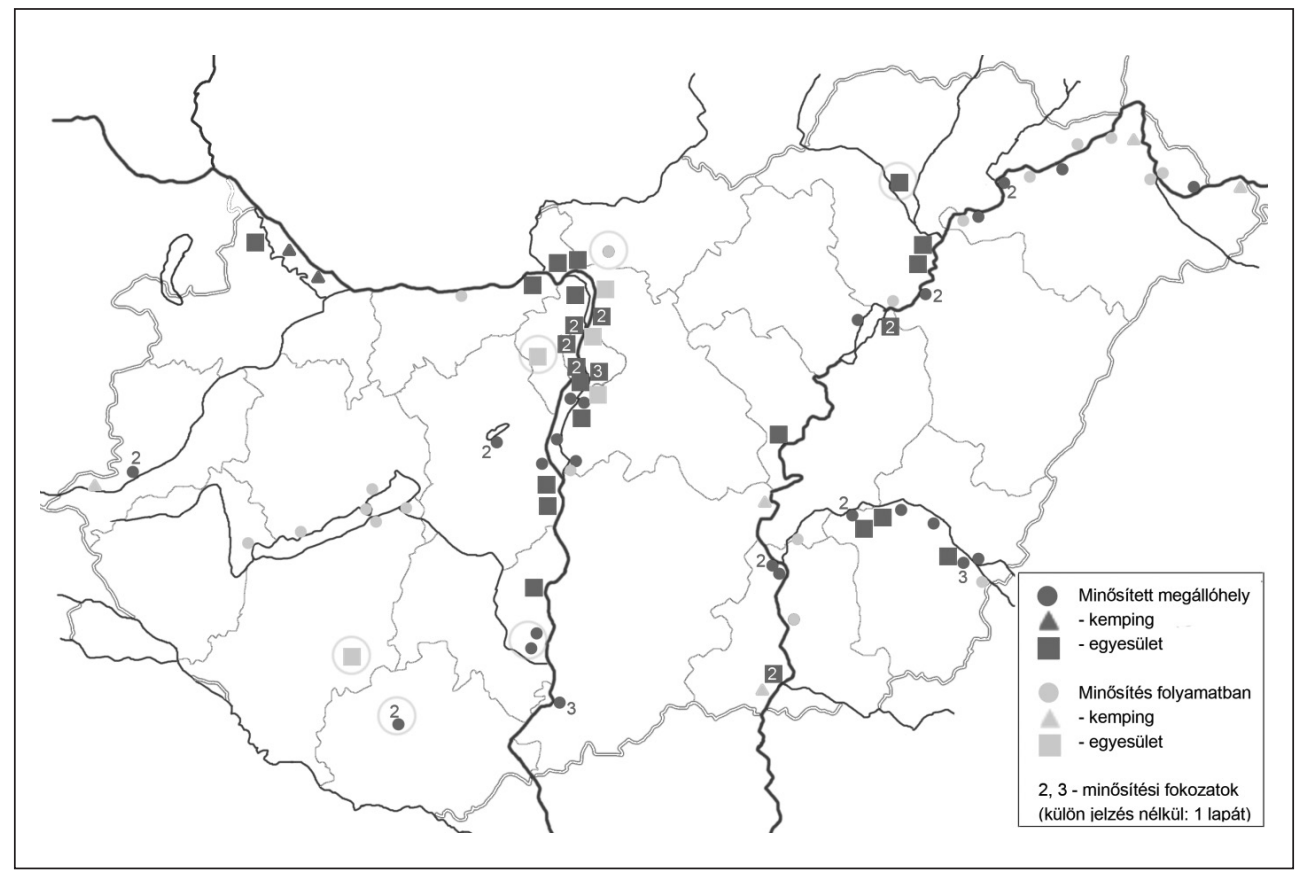

Megjegyzés: A körrel jelzett helyek kisebb állóvizek melletti megállóhelyek: Törökbálinti-tó, Deseda-tó (Kaposvár), Orfúi-tó, Faddi-Duna, Tolnai-Duna, Csorba-tó (Miskolc), Bánki-tó.

Forrás: Saját szerkesztés a Magyar Kajak-Kenu Szövetség adatai alapján

Egyelőre csekély a magasabb minôsítésû megállóhelyek aránya (ezek 71\%-a csak egylapátos minôsítést kapott), ami azt bizonyítja, hogy a hazai folyók mentén még nem áll rendelkezésre megfelelő minôségú turisztikai infrastruktúra. A megállóhelyek minôségében is jól megfigyelhetốk a területi eltérések: míg a Duna vízrendszerében (és ezek többségében közvetlenül a Duna mentén) 26 megállóhely kapott minôsítést (és ennek 27\%-a magasabb egylapátosnál), addig a Tisza vízrendszerében csak 21 megállóhely található, de ezeknek az egyharmada magasabb minôsítésú. Ha azonban a megállóhelyek jellegét vizsgáljuk, látható, hogy a Duna mentén többségben vannak azok a helyek, amelyek vízisport-egyesületek telepei (60\%, a Tisza vízrendszere mentén tapasztalható 38\%-kal szemben). Összességében a minôsített vízitúramegállóhelyek fele egyesületi telephely, így a sportegyesületek (a Magyar Kajak-Kenu Szövetség tevékenységén túl) még nagyobb szerephez jutnak a víziturizmusban. Ez egyrészrôl örvendetes, hiszen ezek a szervezetek rendelkeznek az alapvetố infrastruktúrával, amely alkalmas a vízitúrázás szolgáltatási színvonalának növelésére, másrészrôl azonban hiányosságokra is felhívja a figyelmet, miszerint a turisztikai szaktudás megjelenése továbbra is kétséges, hasonlóképpen, mint ahogyan a mozgalmi jellegból való átalakulás során az alapvetốen sporteszköz-bérbeadással foglalkozó vízitúra-szervezô vállalkozások esetén is. 
Donka Attila - Gyuricza László: Az állam szerepe az aktív turizmus fejlesztésében

\section{A FOLYAMATBAN LÉVÓ INFRASTRUKTÚRA-FEJLESZTÉSEK ÉRTÉKELÉSE}

A természetjáráshoz kapcsolódó turisztikai fejlesztések második üteme - a túraútvonalak és turistaházak fejlesztését követôen - a vízitúra-megállóhelyek kialakítása, illetve fejlesztése. Az alacsony jövedelemtermeló képességgel rendelkezô alap-infrastruktúra megvalósítása azonban nem várható el a vállalkozói szektortól. Számos folyóparti településen már évtizedek óta kialakultak a vízparti turizmus alapfeltételei, ezek azonban sok esetben nem elégítik ki teljes mértékben a vízitúrázók speciális igényeit, sốt, sok esetben azzal ellentétesek is. ${ }^{8}$ Emellett az önkormányzatok is stabilabb bevételnek tekintik a vízparti üdülőturizmust, mint a vízitúrázókat, mind létszámuknál, mind pedig a tartózkodási idejükból is adódó alacsony költésük miatt.

Annak érdekében, hogy ez a helyzet kedvezố irányba mozduljon, igen jelentôs források bevonásával, 2016 tavaszán pályázatokat hirdettek az aktív turizmus szereplôi számára. ${ }^{9}$ Mivel a fejlesztéseket mind területileg, mind pedig ágazatilag központi koordináció mentén tervezik végrehajtani, a pályázók a Bejárható Magyarország Programban meghatározott jármódok országos szervezetei lehetnek: a Magyar Természetjáró Szövetség, a Magyar Vitorlás Szövetség, a Magyar Lovas Turisztikai Szövetség, a Kerékpáros Magyarország Szövetség (és a kerékpárutak fejlesztésében való érintettség miatt a Nemzeti Infrastruktúra Fejlesztô Zrt., illetve várható jogutódszervezete, a Kormányzati Informatikai Fejlesztési Ügynökség) és a Magyar Kajak-Kenu Szövetség.

A vízitúrázás kapcsán az utóbbi szervezet öt külön projektben az ország öt különbözố térségében tervezi vízitúra-megállóhelyek fejlesztését. A fejlesztések helyszínei már jelenleg is ezzel a funkcióval rendelkezô területek. A szövetség a részvétel feltételeként elôírta, hogy az adott helyszín már rendelkezzen lapátos minôsítéssel, így azok többsége önkormányzati üzemeltetésú szabadstrand vagy sporttelep. A projektek keretében sportcélú vízijármúvek számára alkalmas kikötôstégeket, továbbá vizesblokkokat, teakonyhákat és raktárakat alakítanak ki, illetve néhány helyen - föleg a Közép-Magyarország régióban - ingatlanfejlesztés is megvalósul. Az üzleti modell szerint pedig központilag kizárólag a fejlesztést koordinálja a Magyar Kajak-Kenu Szövetség, ezt követốen a helyi szereplốknek kell gondoskodni a fenntartható üzemeltetésról. A megállóhelyek használata a vízitúrázók számára ingyenes lesz, bevételek csupán a kiegészító szolgáltatásokból lehetnek..$^{10} \mathrm{~A}$ Szövetség a megvalósításon túl további támogatást is biztosít a helyszíneknek: közremúködnek a további lapátos minősítések megszerzésében, és a honlaprendszeren keresztül megjelenési lehetôséget is biztosítanak a megállóhelyeknek. ${ }^{11}$

Az elôzetes feltételek miatt a fejlesztésre kerülő helyszínek már most is használt vízitúra-megállóhelyek. Az öt helyszín közé tartozik: Felsô-Tisza-vidék (áthúzódva a Közép-Tisza-vidékre is, Tiszacsegéig, 15 helyszín); Alsó-Tisza-vidék és a Körösök vidéke (szintén áthúzódva a Közép-Tisza-vidékre Szolnokig, 12 helyszín); Alsó-Dunavidék (a Duna Fejér, Bács-Kiskun, Tolna és Baranya megyei szakasza); Felsô-Duna (Győr-Moson-Sopron és a Komárom-Esztergom megyei szakaszok); közös projekt- 
ben a Balaton és a Velencei-tó, valamint a VEKOP-pályázat keretében a Duna és mellékágai a Közép-Magyarország régió területén (16 helyszín). Az egyes helyszínek fejlesztési költsége átlagosan 12-15 millió forint (10 és 30 millió forint között szóródva). Az egyes fejlesztési keretösszegek meglehetôsen magasnak túnnek, különösen a turistaház-felújítási program költségeivel összehasonlítva. Utóbbi esetén az elsố szakaszban 30 turistaház (illetve kilátóhelyek) felújítása (vagy építése) ugyanúgy 2 milliárd forint költséggel valósul meg, mint feleennyi helyszínen olyan túramegállóhelyek - többnyire nem kialakítása, hanem csupán - felújítása, fejlesztése, ahol a közismerten leginkább költséges szálláshelyfejlesztési elemek nem is jelennek meg.

A fejlesztések célterületei egyúttal erôsen behatárolják azokat a térségeket, amelyeken központi támogatással növelni szeretnék a vízitúrázás szerepét. Az ezen kívül esô térségek alap-infrastruktúrájának fejlődése erôsen kérdéses. A többi vízfelület között igen népszerú desztinációk is találhatók (például a Bodrog, a Hernád vagy a Rábamenti területek).

A tavakkal kapcsolatban érdemes megjegyezni, hogy bár a vízitúrázás a rendelkezésre álló eszközök révén nem lehetetlen ugyan a nagyobb állóvizeken, azonban a tevékenység élménytartalma jelentôsen megváltozik, így nem lehet azonos vagy hasonló motivációval rendelkezô piaci szegmensekre alapozni, mint a klasszikus, folyami vízitúrázást.

A fejlesztések kockázatai között kell értékelni a megállóhelyek kihasználásának kérdését is. Az elôzetes projektelemméretek alapján az egyes megállóhelyek kapacitása jóval nagyobb lesz az egyidejúleg várható vízitúrázók létszámánál. A kockázat megvalósulására már jelenleg is van példa: a néhány évvel korábbi, szintén pályázati forrásból megvalósult fejlesztés eszközparkja évekig szinte teljesen kihasználatlanul állt az egyébként igen jelentôs vízitúra-forgalommal rendelkezô Bodrog-parti Szegi községben, majd a fenntartási időszakot követôen eladták azokat.

\section{ÖSSZEFOGLALÁS}

Az aktív turisztikai termékek igen eltérô jellemzôkkel rendelkeznek. Egy részük - például a lovas vagy a kerékpáros turizmus - komolyabb jövedelemtermelô képességgel rendelkezik, míg a természetjárás különbözô formái még csak szabadidôs tevékenységként vannak jelen a piacon. Így míg az elóbbiek esetén maguk a vállalkozások is képesek megteremteni az infrastruktúra bizonyos elemeit, az utóbbi tevékenységek esetén szükség van komoly állami szerepvállalásra is. Az alap-infrastruktúra megteremtése, illetve fejlesztése így még inkább tervszerúen, összehangoltan történhet, annak elônyeit pedig késôbb maguk a szolgáltató vállalkozások is élvezhetik.

A fejlesztések során tehát a leginkább hatékony az, ha az aktív turisztikai termékek alap-infrastrukturális feltételei központi forrásból valósulnak meg, ügyelve az üzemeltetés hosszú távú megoldására. Ezzel megteremthetô a szolgáltatók számára az a feltételrendszer, amellyel már saját és az adott térség erőforrásait használva minôségi szolgáltatásokat tudnak nyújtani. 


\section{Donka Attila - Gyuricza László: Az állam szerepe az aktív turizmus fejlesztésében}

\section{JEGYZETEK}

1 Az Állami Számvevôszék egyik jelentése külön a kerékpáros turizmussal foglalkozik (ÁSZ, 2013), és megállapítja, hogy a támogatásból megvalósult fejlesztések esetén sok esetben a piaci árnál magasabban árazták be a költségeket, továbbá nem gondoskodtak a fenntartáshoz szükséges erôforrásokról sem.

2 A kormányzati kommunikációban az alacsony fizetôképességú szegmenseket jelölték meg célcsoportként. Ez egyrészrôl érthetô ugyan, másrészrôl azonban a szolgáltatások reménybeli további fejlesztését tekintve, a fajlagos bevételek emelésének szándékától való elállást is jelentheti.

3 Az országos kék jelzés ezenfelül kiterjed a Dél-Dunántúlra $(560 \mathrm{~km})$ és az Alföldre $(850 \mathrm{~km})$ is.

4 A program beépült a Nemzeti Alaptantervbe is. A kormány 110/2012. (VI. 4.) Korm. rendelete a Nemzeti alaptanterv kiadásáról, bevezetésérôl és alkalmazásáról.

5 A program megvalósítása kezdetben az Erzsébet-programmal szorosan együttmúködve zajlott, az utóbbi két évben azonban már egy felsôoktatási intézmény kapta meg a feladatot.

${ }_{6}^{6}$ A szervezet vezetôje minden nyilatkozatában az élsportnak rendeli alá a turizmust. Ezt egy nem szakmabeli személytől nem lehet zokon venni, de tekintve a turizmus jövedelemtermelô képességét, szükség volna egy szervezeten belüli képzésre is, a döntéshozók tájékoztatása céljából.

7 Szintén a védjegy, de nem a nemzeti tanúsító védjegyek közé tartozik a lovas szolgáltatók Magyar Lovas Turisztikai Szövetség által kidolgozott patkós minôsítési rendszere.

8 Értve ez alatt például azokat a vízparti zenés szórakozóhelyeket, amelyeket többnyire a helyi lakosság vesz igénybe, miközben az ott tartózkodó turisták igényei épp ezzel ellentétesek.

9 GINOP 7.1.2-15 (és VEKOP 4.1.1-15) „Aktív turisztikai hálózatok infrastruktúrájának fejlesztése” címú felhívások.

10 Ezt a feltételt nem minden üzemeltetô vállalta.

11 A további tervek között szerepel egy foglalási rendszer felépítése, valamint vízi mobilapplikációk kifejlesztése is („vízi waze”, „okosbója”, „river street view”).

\section{FELHASZNÁLT IRODALOM}

ÁSZ (2013): Jelentés a kerékpárút hálózat fejlesztésére forditott pénzeszközök felhasználásának ellenôrzéséröl (párhuzamos ellenôrzés a Szlovák Számvevốszékkel). Állami Számvevôszék, Budapest.

Aubert Antal (2006): A turisztikai nagyberuházások hatása Baranya megye idegenforgalmára. In: Desztinációépités és -menedzsment. Szerk. Aubert Antal, Dél-Dunántúli Regionális Idegenforgalmi Bizottság, Pécs, $5-19$.

Aubert Antal et al. (2007): Turizmus és a terület-, valamint vidékfejlesztés. In: A térségi turizmuskutatás és tervezés módszerei, eredményei. Szerk. Aubert Antal, Pécsi Tudományegyetem, Pécs, 76-132.

Bajmócy Zoltán et al. (szerk.) (2012): Regionális innovációs képesség, versenyképesség és fenntarthatóság. JATEPress, Szeged.

Braunné Fülöp Katalin (2011): Turisztikai beruházások értékelése. NFA Füzetek, 1. évf., 2. sz., 72-78.

Budai Zoltán (2001): A Széchenyi Terv keretében megvalósuló egészségturisztikai fejlesztések első félévének eredményei. Turizmus Bulletin, 5. évf., 3. sz., 3-8.

Dávid Lóránt (2007): Tanácsadói feladatleírás a turisztikai és kulturális beavatkozások célkövetési rendszerének kialakitásához az Új Magyarország Fejlesztési Tervhez (ÚMFT) kapcsolódóan. Végsô jelentés. Good Deal Kft. Nemzeti Fejlesztési Ügynökség.

GKI Gazdaságkutató Zrt. (2005): A turizmus nemzetgazdasági jelentôsége. Turizmus Bulletin, 9. évf., 1. sz., 43-49.

Inskeep, Edward (2000): A fenntartható turizmus fejlesztése. Irányelvek a turizmus tervezôinek és szervezôinek. Geomédia szakkönyvek, Geomédia Kiadó, Budapest.

Kovács Balázs - Gerlach Viktor (2007): A 2007-2013 közötti hazai fejlesztéspolitika turisztikai vetülete. Turizmus Bulletin, 11. évf., 3. sz., 39-46.

Ligeti Ádám (2006): A turisztikai projektek fejlesztésének legfőbb tapasztalatai az európai uniós pályázatok tükrében. Turizmus Bulletin, 10. évf., 2. sz., 35-41. 
Mundruczó Györgyné et al. (2010a): A támogatott turisztikai beruházások helyi és térségi szintű hatékonyságának vizsgálata. Turizmus Bulletin, 14. évf., 4. sz., 53-60.

Mundruczó Györgyné et al. (2010b): A turisztikai fejlesztések állami támogatása térségi és nemzetgazdasági szintú hatékonyságának vizsgálata. Állami Számvevôszék Kutató Intézete, Budapest.

Mundruczó Györgyné - Szennyessy Judit (2005a): A Széchenyi Terv egészségturisztikai beruházásainak gazdasági hatásai. Turizmus Bulletin, 9. évf., 3. sz., 30-41.

Mundruczó Györgyné - Szennyessy Judit (2005b): Az egészségturisztikai fejlesztések gazdasági hatásai Magyarországon. Összefoglaló tanulmány I-II., Polgári Magyarországért Alapítvány által támogatott kutatási tanulmány.

Nemes Andrea (2009): Az állam szerepe a turizmusban. Vezetéstudomány, 40. évf., 5. sz., 53-67.

Magosfa Alapítvány (2010): Pilisi zöldút, természetjáró és tematikus túra utak újszerú megközelítésben. Magosfa Alapítvány.

Raffay Zoltán et al. (2007): Regionális Operatív Program (ROP) „1.1 Turisztikai fogadóképesség javítása” intézkedések javítását célzó értékelō tanulmány. Kutatási zárójelentés, MTA Regionális Kutatások Központja Dunántúli Tudományos Intézete, Pécs.

Sulyok Judit - Magyar Zsuzsanna (2014): Az aktív turizmus helyzete Magyarországon - fókuszban a kerékpározás és a természetjárás. Turizmus Bulletin, 18. évf., 3-4. sz., 15-26.

Trón Zsuzsanna (2008): Az európai uniós támogatások hatásának vizsgálata. Competitio, 7. évf., 1. sz., 83-101.

Vargáné Csobán Katalin (2005): A turizmus fenntarthatóságának értékelése. Agrártudományi Közlemények, 16. évf., különszám, 414-421. 